75 years of Agricultural University - Plovdiv JUBILEE SCIENTIFIC INTERNATIONAL CONFERENCE Plovdiv 26-28 November 2020
PERSPECTIVES ON AGRICULTURAL SCIENCE AND INNOVATIONS FOR SUSTAINABLE FOOD SYSTEMS

\title{
DOI: 10.22620/agrisci.2021.29.014 \\ APPLICATION OF BIOLOGICAL PRODUCTS AT CULTIVATION OF GARDEN PEA PISUM SATIVUM L.
}

\section{Olga Georgieva*, Natalia Karadzhova, Slavka Kalapchieva}

Maritsa Vegetable Crops Research Institute (MVCRI), 32 Brezovsko shosse, 4003 - Plovdiv, Bulgaria

\section{*E-mail: olgaizk@abv.bg}

\begin{abstract}
The possibilities of using the biological products "Trichodermine" (Trichoderma viride Pers ex Fr.), "Gliocladine" (Gliocladium virens Miller et al.) and the mycorrhizal activator "Rhizo VAM Basic" (Glomus intraradices Schenck\&Smith) for control of fungal diseases in garden pea and and their impact on the biometric indicators of young plants were studied. Biological preparations based on antagonistic fungi Trichoderma viride and Gliocladium virens improve the phytosanitary condition of the plants, the mycorrhizal fungus Glomus intraradices stimulates the formation of the root system and tuber formation, but has a weak fungicidal effect against Fusarium wilt in this culture. The experiment was performed on an artificial infectious background by Fusarium oxysporum Schlecht. f. sp. pisi (Hal.) Raillo, isolated from diseased plants. The effect of application of the biological products"Trichodermine" and "Gliocladine" is 34-68\%, from "Rhizo VAM Basic" - 8\% compared to the infected control. The combined application of biological preparations with fungicidal and mycorrhizal action significantly protects the crop from infection with the causative agent of Fusarium wilt of garden pea.
\end{abstract}

Keywords: Pisum sativum L., legume-rhizobial symbiosis, arbuscular mycorrhiza, symbiotic effectiveness, antagonists, Fusarium oxysporum f. sp. pisi.

\section{INTRODUCTION}

Pea Pisum sativum L. is one of the most important legumes used as a source of valuable protein with a high nutritional value. Pea plants can bind atmospheric nitrogen and enrich the soil with organic substances. This makes peas a preferred precursor in crop rotations (Brezhneva, 2007). Growing peas over large areas leads to the accumulation of pathogenic microflora in the soil. One of the limiting factors in the production of green peas in the field is Fusarium root rot and wilting (Orlova, 1999; Papavizas \& Ayers, 1974). The disease is caused by a group of pathogens belonging to the genus Fusarium sp. and has various forms of manifestation (Kraft, 2001). Infection can develop as root rot, rot of beans and cereals, wilting and drying out. The main cause of root rot and green pea wilt is Fusarium oxysporum (Schlecht.) f. sp. pisi (Hal.) Raillo (Sharma, 2010; Stancheva, 2002). Fusarium oxysporum develops in the conducting system of plants and blocks the transfer of water and nutrients to plant organs. As a result of tracheomycosis, plants wither and eventually dry out. The fungus reproduces by mycelium, micro- and macroconidia, chlamydospores and sclerotia. This helps to keep the phytopathogen in the soil and on plant residues. The main stock of infection remains in the soil, therefore, measures to combat the disease should, above all, be aimed at reducing the amount of inoculum in it. In field conditions, controlling 
75 years of Agricultural University - Plovdiv JUBILEE SCIENTIFIC INTERNATIONAL CONFERENCE Plovdiv 26-28 November 2020
PERSPECTIVES ON AGRICULTURAL SCIENCE AND INNOVATIONS FOR SUSTAINABLE FOOD SYSTEMS the infection with chemicals alone does not give a satisfactory result (Akhter et al., 2015). An alternative to the chemical method is to enrich the soil with antagonists and mycorrhizal fungi. Universal agents for biological control of soil pathogens are fungi of the genus Trichoderma (Kim \& Hwang, 2007; $\mathrm{H}$ a $\mathrm{r} \mathrm{m}$ a n, 2000; Papavizas, 1985). It is known that the pre-sowing treatment of legume seeds with a suspension of conidia Trichoderma hamatum (Bon.) protects peas and beans from infection with Pythium sp. and Rhizoctonia solani to the same extent as the fungicide "Captan" (B e $n$ i t e z et al., 2004). It is important to choose a variety with a good ecological plasticity, a high level of nitrogen fixation and a formation of arbuscular mycorrhiza. According to the literature, arbuscular mycorrhiza has a depressant effect against the development of diseases caused by the soil-dwelling fungi (Davis et al, 1979; Davis \& Menge, 1980). The mechanisms of this interaction between the arbuscular mycorrhizal fungi (VAM) and the soil pathogens are diverse, but the cause of disease suppression is not yet known (Abbott et al., 1985; Bever et al., 2002). The aim of the present work is to study the influence of the antagonistic fungi Trichoderma viride and Gliocladium virens and the mycorrhizal fungus Glomus intraradices on the development of green pea under conditions of soil infection with Fusarium oxysporum f. sp. pisi. The effectiveness of the symbiosis and its application for the control of Fusarium root rot and wilting in peas was evaluated.

\section{MATERIALS AND METHODS}

The experimental work was performed as a vessel experiment in greenhouse conditions. For this purpose a pea variety „Puldin“, selection of (MVCRI) was used. The seeds were decontaminated in $1.5 \% \mathrm{NaOCl}$ solution for eight minutes, followed by copious washing in clean water and sown in a sterile peat-perlite mixture in a ratio of 1:2. The biologics "Trichodermine" and "Gliocladine" with a titer of $2.10^{10} \mathrm{c} / \mathrm{g}$ were used at a dose of $2 \mathrm{~g} /$ plant, mycorrhizal preparation "Rhizo VAM Basic"-5 ml/plant before sowing the fungus Glomus intraradices - $5 \mathrm{ml} /$ plant were introduced into each pot. The variants with the introduction of the antagonists separately and in combination with the mycorrhizal fungus were set. The experiment was performed on an artificial infectious background of Fusarium oxysporum isolated from diseased pea plants. Two weeks after germination, the young plants were dipped in the soil and infected with a pure culture of Fusarium oxysporum f. sp. pisi with a titer of $1.10^{8} \mathrm{c} / \mathrm{ml}$, produced in a liquid nutrient medium of Chapek. The dose of the imported inoculum was $5 \mathrm{ml}$ per pot. The biological preparations based on fungal antagonists Trichoderma viride and Gliocladium virens were produced in the laboratory of the (MVCRI) according to the methodology for solid-phase production. We used the trademark of mycorrhizal preparation - "Rhizo VAM Basic". The following biometric parameters of plants were monitored: raw Biomass per plant $(\mathrm{g})$, Length $(\mathrm{cm})$ and Weight $(\mathrm{g})$ of the root, Height $(\mathrm{cm})$ and Weight (g) of the stem, (g) during the flowering phase of green peas. Reporting of Fusarium root rot was made on a 4-point scale:

0 - no symptoms; 1 - slight darkening of the root collar or base of the stem; 2 significant darkening or blackening of the root collar or base of the stem, the rot of the main and lateral roots; 3 - severe rot of the stem, the presence of fungal tissue plant easily removed from soil; 4 - the death of plants (Chekalin, 2003). The Index of Attack was calculated using Mc. Kinnly formula, the Effect of using organic fertilizers - Abbott formula. Each variant contained 20 plants in five replications. Plants were grown in greenhouses with strict watering.The statistical processing of the 
75 years of Agricultural University - Plovdiv

JUBILEE SCIENTIFIC INTERNATIONAL

CONFERENCE Plovdiv 26-28 November 2020
PERSPECTIVES ON AGRICULTURAL SCIENCE AND INNOVATIONS FOR SUSTAINABLE FOOD SYSTEMS obtained experimental data was made with the program Excel (Microsoft Office 2002), Windows XP. The results of the study were analyzed by a standard statistical procedure and presented as a means from three replicates.

\section{RESULTS AND DISCUSSION}

According to scientific observations, peas (Pisum sativum L.) are considered an ideal model crop for studying the functioning of a triple symbiotic system - root, nitrogen-fixing bacteria and mycorrhizal fungi (Shtark et al., 2006). In this paper, the influence of mycorrhizal fungi and antagonists on the development of peas in the conditions of natural infection of plants with nitrogen-fixing bacteria is traced. It was found that inoculation of plants with Glomus intraradix has a positive effect on the biometric parameters of young pea plants - plant height, root length, and raw plant biomass. Probably, the stimulating effect of mycorrhizal biofertilizer is due to the ability (AMH) to increase the absorption of nutrients by the plant (Bolan, 1991; Clark \& Zeto, 2000). Our results confirm the results obtained by other authors (Aleshenkova, 2011; Borisov, 2004). It is known that (AMF) is a widespread group of fungi that form a symbiotic association with various plant species. (AMF) ensure the absorption of nutrients (mainly phosphorus and nitrogen) from the soil and contribute to the survival of plants in adverse environmental conditions. In turn, plants supply arbuscular mycorrhizal fungi with carbohydrates and lipids. Thanks to its powerful enzymes, mycorrhiza decomposes and delivers water-insoluble forms of phosphorus, potassium, and nitrogen, as well as other biologically active substances and trace elements to the host plant. The growthstimulating effect on green peas was well expressed in variants with the introduction of the fungus Trichoderma sp. and Gliocladium sp. (table 1). In these variants, the biometric parameters of plants significantly exceed those in the control variants - plant height by $20 \%$; root length by $50-90 \%$; raw plant biomass - 46$56 \%$ (table 2). The antagonistic fungi Trichoderma sp. and Gliocladium sp. were recognized by researchers as microorganisms capable of acting as growth regulators (Koryagin, 2009). They secrete substances that stimulate plant growth and promote the absorption of insoluble salts and nutrients from the soil solution (Pavlovskaya et al., 2012). The degree of tuber formation in peas is an important indicator causally related to the yield of this crop. Pea varieties differ significantly in their ability to fix atmospheric nitrogen. Therefore, many countries are working to create pea genotypes with a high intensity of symbiotic nitrogen fixation (Naumkina, 2003; Tagimanova et al., 2013). There is a positive relationship between the high yield and the number of tubers formed (Pereira et. al., 1993). To improve nitrogen fixation, artificial inoculation of plants with nitrogen-fixing bacteria is used. In our experience, the formation of tubers occurred naturally and is due to the genetic characteristics of the "Puldin" variety. Accounting for the number of tubers formed on plant roots showed that Trichoderma and Gliocladium fungi contribute to the formation of symbiotic relationships between nitrogen-fixing bacteria and the root in this culture (table 1). The number of tubers formed at the root is the largest in these two variants. For comparison, the use of the mycorrhizal fungus Glomus intraradices does not lead to an increase in the number of tubers at the roots. This is due to a different type of relationship in the biocenosis. The symbiotic relationship of Glomus intraradices and pea plants is due to the formation of arbuscular mycorrhiza. The use of antagonists and mycorrhizal fungus Glomus intraradices in the form of a double inoculation of plants did not have a positive effect on the biometric parameters of plants, compared with the control 
75 years of Agricultural University - Plovdiv JUBILEE SCIENTIFIC INTERNATIONAL CONFERENCE Plovdiv 26-28 November 2020
PERSPECTIVES ON AGRICULTURAL SCIENCE AND INNOVATIONS FOR SUSTAINABLE FOOD SYSTEMS or variants with the introduction of bioproducts separately. The reason for reducing this effect when used together with mycorrhizal fungi and antagonists may be the ability of antagonists to produce toxins. It has been shown that most Trichoderma strains synthesize toxic metabolites that inhibit colonization by other microorganisms (Pavlovskaya et al., 2012). One of the main goals of our study and the study of the effect of application of the antagonistic fungi Trichoderma and Gliocladium combine with the mycorrhizal fungus Glomus intraradices against the development of Fusarium rot and wilt in green pea. It is known that the treatment of the soil with the biological preparations "Trichodermine" and "Gliocladine" signifi-cantly reduces the accumulation of phytopathogen in the soil (Rudakov, 2006). Treatment of the seed with fungi $T$. viride, and $G$. virens is used as a prophylactic to control Fusarium oxysporum (Zhang et al., 1996). The results of the experiment prove the effectiveness of antagonists as a means of combating Fusarium rot root and wilting in green peas. The effect of introducing antagonists into the soil before sowing at a dose of $2 \mathrm{~g}$ per plant (titer $2.10^{10} \mathrm{c} /$ g) on the development of Fusarium root rot and wilting in peas is $34 \%$ in the variant with $T$. viride and $68 \%$ with $G$. virens, respectively.

Table 1. Biometric parameters of plants in the experiment with green pea.

\begin{tabular}{|c|c|c|c|c|c|c|}
\hline \multirow[t]{3}{*}{ Вариант } & \multicolumn{6}{|c|}{ Parameters } \\
\hline & \multirow[b]{2}{*}{$\begin{array}{l}\text { Mass of } \\
\text { plant } \\
(\mathrm{g})\end{array}$} & \multicolumn{2}{|c|}{ Root } & \multicolumn{2}{|c|}{ Stem } & \multirow[b]{2}{*}{$\begin{array}{l}\text { Number of } \\
\text { tubers }\end{array}$} \\
\hline & & $\begin{array}{l}\text { Length } \\
(\mathrm{cm})\end{array}$ & $\begin{array}{l}\text { Mass } \\
(\mathrm{g})\end{array}$ & $\begin{array}{l}\text { Height } \\
(\mathrm{cm})\end{array}$ & $\begin{array}{l}\text { Mass } \\
(\mathrm{g})\end{array}$ & \\
\hline $\begin{array}{l}\text { Control with } \\
\text { infection }\end{array}$ & 15,96 & 16,25 & 0,33 & 51,75 & 15,63 & 24,33 \\
\hline $\begin{array}{l}\text { Control without } \\
\text { infection }\end{array}$ & 17,59 & 21,45 & 0,50 & 64,00 & 17,09 & 27,50 \\
\hline Trichoderma viride & 23,43 & 17,91 & 0,52 & 63,66 & 22,91 & 26,11 \\
\hline Gliocladium virens & 24,83 & 16,15 & 0,63 & 55,20 & 24,20 & 35,80 \\
\hline Glomus intraradices & 22,78 & 20,23 & 0,69 & 62,14 & 22,09 & 47,70 \\
\hline $\begin{array}{l}\text { Glomus intraradices } \\
+ \text { Trichoderma } \\
\text { viride }\end{array}$ & 17,98 & 16,11 & 0,54 & 48,66 & 17,44 & 27,00 \\
\hline $\begin{array}{l}\text { Glomus intraradices } \\
+ \text { Gliocladium } \\
\text { virens }\end{array}$ & 18,92 & 22,33 & 0,59 & 50,41 & 18,33 & 29,38 \\
\hline GD $0,05 \%$ & 1,078 & 0,65 & 0,169 & 1,72 & 0,097 & 0,036 \\
\hline
\end{tabular}

The results of using Glomus intraradices in our experiment do not differ from the results obtained by other researchers (Bødker et al., 1998; Kjøller \& Rosendahl, 1996). The effect against the development of Fusarium root rot and wilting on peas from the independent use of the mycorrhizal fungi is about $8 \%$.
When the fungus $T$. viride and $G$. virens were used together with $G$. intraradices in the soil experiments, we reported an increase in the antagonistic properties of the fungus. This is probably due to two main factors - the maximum absorption of phosphorus by plants under the influence of mycorrhiza and the 
75 years of Agricultural University - Plovdiv JUBILEE SCIENTIFIC INTERNATIONAL CONFERENCE Plovdiv 26-28 November 2020
PERSPECTIVES ON AGRICULTURAL SCIENCE AND INNOVATIONS FOR SUSTAINABLE FOOD SYSTEMS release of antibiotics and toxins from antagonists.

Despite the contradictory results obtained with the combined use of antagonistic fungi Trichoderma viride and Gliocladium virens and mycorrhizal fungus Glomus intraradices on the development of green pea in soil contamination with Fusarium oxysporum f. sp. pisi, we can draw the main conclusions about the effectiveness of symbiosis and its use to combat Fusarium root rot and wilting of peas.

Table 2. Effect of application of Trichoferma viride, Gliocladium virens and Glomusintraradices on the biometric parameters of plants in green pea.

\begin{tabular}{|l|c|c|c|c|}
\hline \multirow{2}{*}{ Вариант } & \multicolumn{3}{|c|}{ Effect to infected control (\%)/parameter } \\
\cline { 2 - 5 } & $\begin{array}{c}\text { Mass of } \\
\text { plant } \\
(\mathrm{g})\end{array}$ & $\begin{array}{c}\text { Mass of } \\
\text { root } \\
(\mathrm{cm})\end{array}$ & $\begin{array}{c}\text { Height } \\
\text { of stem } \\
(\mathrm{cm})\end{array}$ & $\begin{array}{c}\text { Number of } \\
\text { tubers }\end{array}$ \\
\hline Trichoderma viride & 46,80 & 57,58 & 23,01 & 7,32 \\
\hline Gliocladium virens & 55,58 & 90,91 & 6,67 & 47,14 \\
\hline Glomus intraradices & 42,73 & 109,1 & 20,08 & 96,05 \\
\hline $\begin{array}{l}\text { Glomus intraradices }+ \\
\text { Trichoderma viride }\end{array}$ & 11,40 & 63,64 & - & 11,00 \\
\hline $\begin{array}{l}\text { Glomus intraradices }+ \\
\text { Gliocladium virens }\end{array}$ & 18,55 & 78,79 & - & 20,77 \\
\hline
\end{tabular}

Table 3. Effect of biological products on the development of Fusarium root rot and wilting in green pea.

\begin{tabular}{|c|l|c|c|}
\hline No & \multicolumn{1}{|c|}{ Variant } & $\begin{array}{c}\text { Index of Attack, } \\
\%\end{array}$ & $\begin{array}{c}\text { Effect to infected } \\
\text { Control } \\
\%\end{array}$ \\
\hline 1 & Control with infection & 45,45 & - \\
\hline 2 & Control without infection & 37,50 & 17,49 \\
\hline 3 & Trichoderma viride & 30,00 & 33,99 \\
\hline 4 & Gliocladium virens & 14,28 & 68,58 \\
\hline 5 & Glomus intraradices & 41,66 & 8,33 \\
\hline 6 & Glomus intraradices + Trichoderma viride & 0,00 & 100,00 \\
\hline 7 & Glomus intraradices + Gliocladium virens & 0,00 & 100,00 \\
\hline
\end{tabular}

\section{CONCLUSIONS}

The fungi Trichoderma sp. and Gliocladium sp. have a pronounced growthstimulating effect on green pea. The weight of the plant is $46-56 \%$ more than the control variant, and the height of the stem is $20 \%$ higher.

Trichoderma and Gliocladium fungi contribute to the formation of a symbiotic relationship between nitrogen-fixing bacteria and the root in this culture. The number of formed tubers exceeds by $\%$ those in the control variant from 7 to $47 \%$.

The inoculation of Glomus intraradices plants has a positive effect on the biometric parameters of young pea plants - plant height, root length, and raw plant biomass.

The use of antagonists Trichoderma sp. and Gliocladium sp. with the mycorrhizal fungus Glomus intraradices in the form of a 
75 years of Agricultural University - Plovdiv JUBILEE SCIENTIFIC INTERNATIONAL CONFERENCE Plovdiv 26-28 November 2020
PERSPECTIVES ON AGRICULTURAL SCIENCE AND INNOVATIONS FOR SUSTAINABLE FOOD SYSTEMS double inoculation of plants does not have a positive effect on the plant biometrics.

The fungicidal effect against Fusarium root rot and wilting in green pea is from $34 \%$ to $68 \%$ when using antagonistic fungi $T$. viride and $G$. virens and $8 \%-G$. intraradices.

When the fungi $T$. viride and $G$. virens are used together with $G$. intraradices, the antagonistic properties of the fungus are enhanced.

The results of the experiment demonstrate the benefits of the combined use of mycorrhizal and antagonistic fungi in the production of green pea.

\section{ACKNOWLEDGMENT}

This work was supported by the Bulgarian Ministry of Education and Science under the National Research Programme "Healthy Foods for a Strong Bio-Economy and Quality of Life" approved by DCM \# 577 / 17.08.2018".

\section{REFERENCES}

Abbott, L. \& A. Robson. 1985. Formation of external hyphae in soil by four species of vesicular-arbuscular mycorrhizal fungi. New Phytol. 99:245-255.

Akhter, W., M.Bhuiyan, F. Sultana \& $M$. Hossain. 2015. Integrated effect of microbial antagonist, organic amendment, and fungicide in controlling seedling mortality (Rhizoctonia solani) and improving yield in pea (Pisum sativum L.). Comptes Rendus Biologies. 338(1): 218.

Aleschenkova, Z. 2011. Influence of arbuscular mycorrhizal fungus on the growth and development of plants. Science and Innovation. 2(96): 59-63 (Ru).

Be nitez, T., M. Rincon, M. Limon, A. Codon. 2004. Biocontrol mechanisms of Trichoderma strains. International Microbiology, 7: 249-260.

Bever, J., S.Richardson, B. Lawrence, J. Holmes and M. Watson. 2009. Preferential allocation to beneficial symbiont with spatial structure maintains mycorrhizal mutualism. Ecol. Lett. 12: 13-21.

Bødker, L., R. Kjøller, S. Rosendahl. 1998. Effect of phosphate and the arbuscular mycorrhizal fungus Glomus intraradices on disease severity of root rot of peas (Pisum sativum) caused by Aphanomyces euteiche. Mycorrhiza. 8:169-174.

Bohrer, K., C. Friese \& J. Amon. 2004. Seasonal dynamics of arbuscular mycorrhizal fungi in differing wetland habitats. Mycorrhiza. 14: 329-337.

Bolan, N. 1991. A critical review on the role of mycorrhizal fungi in the uptake of phosphorus by plants. Plant Soil 134: 189-207.

Borisov, A. 2004. Efficiency of using joint inoculation of peas (Pisum sativum L.) with arbuscular mycorrhiza fungi and nodule bacteria to increase plant productivity in sustainable environmentally oriented agriculture. In: Reports of the Russian Agricultural Academy. 2: 12-14.

Brezhneva, V. 2007. Garden Pea - a necessary crop in crop rotation. Plant Protection in the Krasnodar territory. Regional Appendix. 11:1-3.

Chekalin, N. 2003. Genetic bases of collection of legumes of resistance to pathogens. Poltava Press. 2004 p.

Clark, R. \& B. Zeto. 2000. Mineral acquisition by arbuscular mycorrhizal plants. J. Plant Nutrition. 23: 867-902.

Davis, R.\& J. Menge. 1980. Influence of Glomus fasciculatus and soil phosphorus on Phytophtora root rot of citrus. Phytopathology. 70: 447-452. 
75 years of Agricultural University - Plovdiv JUBILEE SCIENTIFIC INTERNATIONAL CONFERENCE Plovdiv 26-28 November 2020
PERSPECTIVES ON AGRICULTURAL SCIENCE AND INNOVATIONS FOR SUSTAINABLE FOOD SYSTEMS
Davis, R., J. Menge, D. Erwin. 1979. Influence of Glomus fasciculatus and soil phosphorus on Verticillium wilt of cotton. Phytopathology. 69: 453-456.

Fester, T.\& G. Hause. 2005. Accumulation of reactive oxygen species in arbuscular mycorrhizal roots. Mycorrhiza, 15: 373-379.

Garbaye, J. 1991. Biological interactions in the mycorrhizosphere. Experientia.

H a r m a n, G. 2000. Myths and dogmas of biocontrol. Changes in perceptions derived from research on Trichoderma harzianum T22. Plant Dis., 377-393.

Ikrina, M. \& A. Kolbin. 2004. Regulators of Plant Growth and Development, Vol. 1: Stimulants. Moscow, "Chemistry". 47:370-375.

Kaye, J., F. Pfleger, E. Steward. 1984. Interaction of Glomus fasciculatum and Pythium ultimum on greenhouse-grown poinsetta. Can. J. Bot. 62: 1572-1579.

Kim, B. \& B. Hwang. 2007. Microbial fungicides in the control of plant diseases. Journal of Phytopathology. 155(11-12): 641-653.

Kjøller, R., S. Rosendahl. 1996. The presence of the arbuscular mycorrhizal fungus Glomus intraradices influences enzymatic activities of the root pathogen Aphanomyces euteiches in pea roots. Mycorrhiza. 6: 487-491. Koryagin, $Y u$. 2009. Influence of biological products and microelements on the growth and development of pea plants. Achievements of Science and Technology in Agriculture. 5: 26-28.

Kraft J., W. Boge. 2001. Root characteristics in pea in relation to compaction and Fusarium root rot. Plant disease. 9(85): 936-940.

Linser A., L. Cazzara, G. Barbieri. 2006. Plant growth promoting rhizobacteria: a new opportunity for a sustainable agriculture. Fertilitas Agrorum. 1: 65-
75.

Naumkina, T. 2003. Pea (Pisum sativum L.) genes implicated in development of symbiotic compartments in nitrogenfixing nodules and arbuscular mycorrhiza. 11-th International Congeess on Molecular Plant-Microbe Interactions. St. Peterburgs, Russia. p. 59-63.

Orlova, E. 1999. Biotic relationships of pea root rot pathogens with soil mycobiota and the possibility of their use in biological protection. Thesis. $122 \mathrm{p}$.

Papavizas, G. \& W. Ayers. 1974. Aphanomyces species and their root diseases in pea and sugarbeet. Agricultural Research Service, United States Department of Agriculture, Technical.

Papavizas, G. 1985. Trichoderma and Gliocladium: Biology, ecology, and potential for biocontrol. Annu. Rev. Phytopathol. 23(1): 23-54.

Pavlovskaya, $N$. et al. 2012. Influence of secondary metabolites of fungi of the genus Trichoderma on the sowing qualities of pea seeds. Agricultural biology. 3: 114-116.

Pereira R. et al. 1993. The Florida Entomologist vol. 76 (1): 63-74.

Rudakov, V. 2006. Biological method in the system of plant protection. Journal of Greenhouse Technologies: 3 (8): 1-5.

Sharma, A., R. Rathour, P. Plaha, V. Katoch, G. Khalsa, V. Patial, Yu. Singh, N. Pathania. 2010. Induction of Fusarium wilt (Fusarium oxysporum f. sp. pisi) resistance in garden pea using induced mutagenesis and in vitro selection techniques. Euphytica. 173:345-356.

Shtark, O. 2006. Analysis of pea (Pisum sativum L.) source material for breeding of cultivars with high symbiotic potential and choice of criteria for its evaluation. Environmental Genetics. 
75 years of Agricultural University - Plovdiv JUBILEE SCIENTIFIC INTERNATIONAL CONFERENCE Plovdiv 26-28 November 2020
PERSPECTIVES ON AGRICULTURAL SCIENCE AND INNOVATIONS FOR SUSTAINABLE FOOD SYSTEMS

4(2):22-28.

Stancheva, I. 2002. Diseases of field crops, In: Atlas of diseases of agricultural crops. v. 3. 184 p. Sofia.

Tagimanova, D., Zh. Rashidenova, $O$. Khapilina. 2013. Screening of resistant pea callus (Pisum sativum L.) with selective media containing Fusarium oxysporum culture filtrate. Biotechnology. Theory and practice. 3: 55-60.

Willis, A., B. Rodrigues \& P. Harris. 2013. The Ecology of Arbuscular Mycorrhizal Fungi, Critical Reviews in Plant Sciences, 32(1): 1-20.

Zhang, J., C, Howell, J. Starr. 1996. Suppression of Fusarium colonization of cotton roots and Fusarium wilt by seed treatments with Gliocladium virens and Bacillus subtilis. Biocontr. Sci. and Technol. 6(2):175-187. 